\title{
SCIENTIFIC REPORTS

\section{Occurrence of 3-nitrobenzanthrone and other powerful mutagenic polycyclic aromatic compounds in living organisms: polychaetes}

\author{
Maria Claudia R. Sola ${ }^{1,2}$, Aldenor G. Santos ${ }^{1,2,3}$, Sabrina T. Martinez ${ }^{1,2}$, \\ Madson M. Nascimento ${ }^{2,3}$, Gisele O. da Rocha ${ }^{1,2,3}$ \& Jailson B. de Andrade ${ }^{1,2,4^{*}}$
}

In this work we report the occurrence of powerful mutagenic 3-nitrobenzanthrone (3-NBA), in addition to 18 polycyclic aromatic hydrocarbons (PAHs), 6 oxygenated PAHs and 27 nitrated PAHs in polychaete worms. Benzanthrone (BA), another important mutagenic polycyclic aromatic compound (PAC) also was detected in the samples. Polychaete annelids have great ecological relevance, being widely distributed in different environmental conditions, from intertidal zones up to seven thousand feet deep areas. They are abundantly found in both contaminated and uncontaminated areas and, therefore, used as indicators of the pollution status of a given area. As we know, so far, most of these PACs has not been previously reported in living organisms before. The 3-NBA concentrations determined in this study were within $0.11-5.18 \mu \mathrm{g} \mathrm{g}^{-1}$. Other relevant PACs such as PAHs, quinones and nitro-PAHs were found in maximum concentrations at $0.013 \mu \mathrm{gg}^{-1}$ (coronene) to $11.1 \mu \mathrm{gg}^{-1}$ (benzo[k]fluoranthene), $0.823 \mu \mathrm{g} \mathrm{g}^{-1}$ (9,10-phenenthrenequinone) to $12.1 \mu \mathrm{g} \mathrm{g}^{-1}$ (1,4-benzoquinone) and 0.434 (1-nitronaphthalene) $\mu \mathrm{g} \mathrm{g}^{-1}$ to $19.2 \mathrm{\mu g} \mathrm{g}^{-1}$ (6-nitrobenzo[a]pyrene), respectively. Principal component analysis (PCA), ternary correlations and diagnostic ratios were employed in order to propose probable sources for PACs. Although statistical analysis preliminarily has indicated both pyrogenic and petrogenic contributions, petrogenic sources were predominant reflecting the impacts of petroleum exploration and intensive traffic of boats in the study area.

Within the last several decades, estuarine and coastal environments (principally those in the vicinities of urbanized, industrialized, and/or populated areas) have been heavily impacted or have had the pollution status aggravated by a variety of anthropogenically-emitted organic and inorganic pollutants ${ }^{1-7}$. Coastal and estuarine ecosystems are complex systems subjected to significant limitations in physical and chemical processes (e.g., tides, freshwater intakes, temperature variations, among others) and may also be exposed to high contaminant concentrations. Many persistent chemical pollutants such as polycyclic aromatic compounds (PACs) are deposited in these ecosystems where they may cause damage to the benthic environment and are likely to become biomagnified through the food chain, ultimately posing risks to human health ${ }^{8}$.

Due to the inherent hydrophobicity and lipophilicity of some PACs such as polycyclic aromatic hydrocarbons (PAHs), once they are released into water bodies they tend to be primarily bound to suspended particles in the water column, and are eventually deposited on the seafloor in sediments and particles where they may be rapidly accumulated by marine benthic invertebrates such as polychaetes worms. Hence, marine polychaetes are well known for their PAH metabolism capabilities, although the ability to metabolize PAHs may widely vary among families ${ }^{1,2,4,9-20}$

In October 1997 the first paper was published registering the isolation of 3-nitrobenzanthrone (3-NBA) from the organic extract of both diesel exhaust and airborne particles. 3-NBA was identified as a new class of powerful direct mutagen and was called "the devil in the diesel"21. Due to it has induced the highest number of revertants

${ }^{1}$ Instituto Nacional de Ciência e Tecnologia em Energia e Ambiente - INCT, Universidade Federal da Bahia, 40170115, Salvador, BA, Brazil. ${ }^{2}$ Centro Interdisciplinar em Energia e Ambiente - CIEnAm, Universidade Federal da Bahia, 40170-115, Salvador, BA, Brazil. 'Instituto de Química, Universidade Federal da Bahia, Campus de Ondina, 40170-115, Salvador, BA, Brazil. ${ }^{4}$ Centro Universitário SENAI-CIMATEC, 41650-110, Salvador, BA, Brazil. *email: jailsondeandrade@gmail.com 
per nanomole in the Ames test to date. In this way, 3-NBA, a nitroketone polycyclic aromatic compound, has attracted much attention from the scientific community due to its genotoxic and mutagenic potential even if present in extremely small quantities in diesel exhaust particles ${ }^{22-26}$.

Although the occurrence of traditional PAHs and other petroleum-related substances in abiotic compartments of marine environments have been subject of several studies ${ }^{6,27-30}$, much less attention has been paid to the effects of these substances on living organisms, which some of them may be the base of the marine food chain (i.e. polychaetes). Consequently, little is also known about the possible endpoints of these pollutants may induce in different trophic levels. Polychaetes are likely to be resistant to high levels of organic pollutants in marine environments $^{4,11,31-34}$. For instance, it is commonly cited the opportunism of the genus Capitella due to the ability to remediate sediments contaminated with organic pollutants ${ }^{18}$.

The main objective of the present study was to investigate the occurrence of "unconventional" PACs in polychaetes. Thus, we determined the concentrations of 3-NBA and 18 PAHs, 27 nitro-PAHs and 6 oxy-PAHs in polychaete samples from different families. Traditional sample preparation procedures for chromatographic analysis of marine living organisms may involve the use of Soxhlet extraction or other traditional techniques, which involve additional laborious and time-consuming clean-up and fractionating steps. Thus, an alternative and very effective sample preparation method for solid-liquid microextraction of polychaetes organisms was employed, which involves the direct extraction using masses as lower as 8 to $200 \mathrm{mg}$ of polychaetes and $500 \mu \mathrm{L}$ of the extraction solvent ( $18 \%$ acetonitrile in dichloromethane). Multivariate statistical analysis and binary and ternary correlations were performed to better understand the occurrence of these compounds in living organisms. To date, this is the first time that 3-NBA, amongst a comprehensive list of PAHs, quinones, and nitro-PAHs, are reported in polychaetes collected from a marine area.

\section{Results and Discussion}

Chromatographic analysis and identification of PACs. In our previous works $\mathrm{s}^{35,36}$ we developed a chromatographic method for simultaneous determination of PACs, including PAHs, nitro-PAHs and quinones associated to atmospheric particulate matter by gas chromatography coupled to mass spectrometry (GC-MS), demonstrating that 3-NBA is emitted directly from vehicles and diesel combustion and that 2-NBA is formed during aerosol transport into the atmosphere. In the present work, we focused on the relationships among 3-NBA, benzanthrone (BA), and related PAHs, quinones and nitro-PAHs in polychaete worms. The 3-NBA, BA and other PACs were identified based on both its retention time and mass spectrum, which were acquired in SCAN mode. Furthermore, BA was well-separated from 3-NBA (Fig. S1A,B) and other PACs in the applied chromatographic conditions (Figs. S2-S5).

In order to approach the unequivocal identification of BA and 3-NBA, we monitored two $\mathrm{m} / \mathrm{z}$ ions, i.e., the ion base and the reference ions for each compound (Table S1). In this way, BA was identified by using $\mathrm{m} / \mathrm{z} 230$ (ion base) and $\mathrm{m} / \mathrm{z} 202$ (Fig. S1C). In turn, 3-NBA (Fig. S1D) was identified by m/z 275 (base ion) and $\mathrm{m} / \mathrm{z} 245$ (reference ions). Quantification was carried out by further considering the ion base signal only, in SIM mode.

Occurrence of polycyclic aromatic compounds in polychaetes collected in the Todos os Santos Bay (BTS) region. As shown in Table 1, low-molecular-weight (LMW) PAHs such as naphthalene (NAP), acenaphthylene (ACY), acenaphthene (ACE), fluorene (FLU), phenanthrene (PHE), and anthracene (ANT) were detected in all analyzed samples with maximum concentrations ranging from $0.800 \mu \mathrm{gg}^{-1}$ dry weight (dw) (ANT)

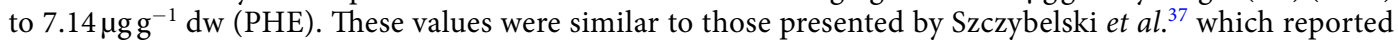
LMW PAH concentrations in the range of $0.149 \mu \mathrm{gg}^{-1} \mathrm{dw}$ (ANT) to $2.46 \mu \mathrm{gg}^{-1}$ (PHE) and $0.100 \mu \mathrm{g} \mathrm{g}^{-1} \mathrm{dw}_{\mathrm{w}}$ (ANT) to $2.28 \mu \mathrm{g} \mathrm{g}^{-1} \mathrm{dw}$ (PHE) for polychaetes Nephtys ciliata and Alitta virens, respectively. In that study the authors analyzed the PAH content in polychaetes living in impacted sediment collected in Oosterchelde Estuary, Netherlands. In turn, high molecular weight (HMW) PAHs such as fluoranthene (FLT), pyrene (PYR), benzo(a) pyrene $(\mathrm{BaP})$, and benzo(ghi)perylene (BgP) were detected in $82.8-100 \%$ samples in the present work. Although these compounds have been reported with a high frequency of detection, their maximum concentration range (0.013-0.600 $\left.\mathrm{gg}^{-1} \mathrm{dw}\right)$ were lower than those observed for LMW PAHs, except for benzo(k)fluoranthene (BkF), which was found in concentrations above $11.0 \mu \mathrm{gg}^{-1} \mathrm{dw}$. In a work published by Nesto et al. ${ }^{38}$, the concentrations of HMW PAHs such as PYR and benzo(a)anthracene (BaA) (ranging from 0.0066 to $0.039 \mu \mathrm{gg}^{-1} \mathrm{dw}$, and from not detected to $59.3 \mu \mathrm{g} \mathrm{g}^{-1} \mathrm{dw}$, respectively) were determined in two lagoon sites in Venice, Italy. These sites were close to a system of navigable channels with intense shipping traffic and were in the vicinity of an industrial plant in the port of the city. These concentrations were very similar to the majority of samples collected in the sites from Todos os Santos Bay, BTS (from Portuguese, Baía de Todos os Santos, BTS, located in Northeastern Brazil) (median $\left.0.003-0.033 \mu \mathrm{gg}^{-1}\right)$ but were lower than the maximum concentration of PYR $\left(0.367 \mu \mathrm{g} \mathrm{g}^{-1} \mathrm{dw}\right)$ and BaA $\left(0.121 \mu \mathrm{g} \mathrm{g}^{-1} \mathrm{dw}\right)$. The BTS sites were characterized by intense shipping and small boat traffic, waste discharge, and petroleum exploration that may have contributed to the concentrations of these organic pollutants found in polychaetes. Table 1 shows the PAC concentrations determined in this study and provides comparisons with other published data.

Nitronaphthalenes were detected in most samples (82.6-100\%) with median values ranging from $0.064 \mu \mathrm{gg}^{-1}$ to $0.203 \mu \mathrm{gg}^{-1}$. However, their concentrations did not exceed $3.0 \mu \mathrm{gg}^{-1} \mathrm{dw}$, except for 1-methyl-5nitronaphthalene (1M-5NNAP) which was present in concentrations up to $12.2 \mu \mathrm{gg}^{-1} \mathrm{dw}$. The concentrations of these nitro-PAHs may be explained by the abilities of polychaetes to absorb and/or bioaccumulate many organic pollutants ${ }^{4,17,20,39,40}$. For instance, K. Ito et al. ${ }^{40}$ investigated the bioaccumulation capacity of the oligochaete Thalassodrilides sp. and the polychaete Perinereis nuntia for nitro-PAHs such as 1-nitronaphthalene (1-NNAP). Organisms were exposed to $1400 \mathrm{\mu g} \mathrm{L}^{-1}$ of 1-NNAP in seawater for three days in the dark at $20^{\circ} \mathrm{C}$. They observed an increase in the 1-NNAP content from 0.012 to $0.094 \mu^{-1} \mathrm{~g}^{-1}$ (an approximately $8 \mathrm{x}$ increase) in Thalassodrilides sp. and from $0.9 \mathrm{ng} \mathrm{g}^{-1}$ to $38 \mu \mathrm{gg}^{-1}$ in P. nuntia (more than $42,000 \mathrm{x}$ increase), showing that $P$. nuntia has a 


\begin{tabular}{|c|c|c|c|c|c|c|c|c|}
\hline \multirow{2}{*}{\multicolumn{4}{|c|}{\begin{tabular}{|l|} 
This work \\
\end{tabular}}} & \multicolumn{3}{|c|}{ Comparison with other published works } & \multirow{2}{*}{\multicolumn{2}{|c|}{ Uno et al. ${ }^{41}$}} \\
\hline & & & & \multicolumn{2}{|c|}{ Szczybelski et al. ${ }^{16}$} & \multirow{2}{*}{\begin{tabular}{|l|} 
Nesto et $a l^{38}$ \\
Range $\left(\mu \mathrm{g} \mathrm{g}^{-1}\right)$
\end{tabular}} & & \\
\hline PAHs & Median & Range & \multirow[b]{2}{*}{ FOD (\%) } & \multirow{2}{*}{\begin{tabular}{|l|} 
Range $\left(\mu \mathrm{g} \mathrm{g}^{-1}\right)$ \\
N. ciliata*
\end{tabular}} & \multirow[b]{2}{*}{ A. virens* } & & \multicolumn{2}{|c|}{ Range $\left(\mu \mathrm{g} \mathrm{g}^{-1}\right)$} \\
\hline Compounds & $\left(\mu \mathrm{g} \mathrm{g}^{-1} \mathrm{dw}\right)$ & $\left(\mu \mathrm{g} \mathrm{g}^{-1} \mathrm{dw}\right)$ & & & & P. rullieri* & Oysters & Mussels \\
\hline (NAP) & 0.243 & $0.020-5.52$ & 100 & - & - & - & - & - \\
\hline (ACY) & 0.094 & $0.005-1.91$ & 100 & - & - & - & - & - \\
\hline (ACE) & 0.147 & $<$ LOD-5.12 & 100 & - & - & - & - & - \\
\hline (FLU) & 0.303 & $0.038-4.27$ & 100 & - & - & - & - & - \\
\hline (PHE) & 0.367 & $0.053-7.14$ & 100 & $0.729-2.46$ & $1.32-2.28$ & $0.0095-0.029$ & - & - \\
\hline (ANT) & 0.042 & $0.030-0.800$ & 100 & $0.149-0.336$ & $0.100-0.113$ & - & - & - \\
\hline (FLT) & 0.033 & $<$ LOD- 0.330 & 100 & \begin{tabular}{|l|}
$1.77-4.47$ \\
\end{tabular} & $1.60-3.15$ & nd -0.026 & - & - \\
\hline (PYR) & 0.033 & $<$ LOD - 0.367 & 100 & $1.38-3.76$ & $0.893-2.034$ & $0.0066-0.039$ & - & - \\
\hline$(\mathrm{BaA})$ & 0.003 & $<$ LOD -0.121 & 68.9 & $0.077-0.218$ & $0.083-0.134$ & $\begin{array}{l}59.26-0.00 \mathrm{nd}- \\
0.059\end{array}$ & - & - \\
\hline (CRY) & 0.002 & $<$ LOD - 0.196 & 48.3 & $1.5 \times 10^{-4}-6.43$ & n.d. -0.887 & $<$ LOD -0.0097 & - & - \\
\hline$(\mathrm{BbF})$ & 0.009 & $<$ LOD -0.600 & 72.4 & $0.100-0.228$ & $0.100-0.151$ & - & - & - \\
\hline$(\mathrm{BkF})$ & 0.159 & $<$ LOD - 11.1 & 82.8 & - & - & $<$ LOD -0.0033 & - & - \\
\hline (BaP) & 0.040 & $<$ LOD - 0.543 & 82.8 & - & - & $<$ LOD -0.0048 & - & - \\
\hline (PER) & 0.023 & $<$ LOD - 0.254 & 65.5 & - & - & - & - & - \\
\hline (IND) & 0.037 & $<$ LOD - 0.281 & 82.2 & 0.034 - n.d. & $0.068-0.096$ & - & - & - \\
\hline (DBA) & 0.008 & $<$ LOD -0.090 & 58.6 & \begin{tabular}{|l|}
$0.040-0.166$ \\
\end{tabular} & $0.115-0.239$ & nd - 0.0043 & - & - \\
\hline (BgP) & 0.067 & $<$ LOD - 0.446 & 96.6 & $0.344-1.106$ & n.d. -0.134 & $<$ LOD -0.029 & - & - \\
\hline$(\mathrm{COR})$ & 0.001 & $<$ LOD - 0.013 & 51.7 & - & - & - & - & - \\
\hline Oxy-PAHs & & Range $\left(\mu \mathrm{g} \mathrm{g}^{-1}\right)$ & FOD (\%) & & & & & \\
\hline$(1,4-B Q)$ & 0.124 & $<$ LOD - 12.1 & 82.8 & - & & - & - & - \\
\hline$(1,2-\mathrm{NQ})$ & $<$ LOD & - & 93.1 & - & & - & - & - \\
\hline (1,4-NQ) & 0.162 & $<$ LOD - 4.57 & 89.7 & - & & - & - & - \\
\hline$(9,10-A Q)$ & 0.221 & $0.019-2.20$ & 93.1 & - & & - & - & - \\
\hline$(9,10-P Q)^{A V}$ & 0.084 & $0.099-0.823$ & 44.8 & - & & - & - & - \\
\hline (BA) & 0.031 & $<$ LOD -0.520 & 82.8 & - & & - & - & - \\
\hline Nitro-PAHs & & Range $\left(\mu \mathrm{g} \mathrm{g}^{-1}\right)$ & FOD(\%) & & & & & \\
\hline (1-NNAP) & 0.064 & $<$ LOD -0.434 & 100 & - & & - & $\begin{array}{l}3.23 \times 10^{-4}- \\
4.78 \times 10^{-3}\end{array}$ & $\begin{array}{l}4.38 \times 10^{-4}- \\
7.63 \times 10^{-3}\end{array}$ \\
\hline (2-NNAP) & 0.041 & $<$ LOD -0.784 & 100 & - & & - & $\begin{array}{l}1.4 \times 10^{-5} \\
8.25 \times 10^{-3}\end{array}$ & $\begin{array}{l}3.80 \times 10^{-4}- \\
6.44 \times 10^{-3}\end{array}$ \\
\hline (1M-4NNAP) & 0.038 & \begin{tabular}{|l|}
$0.010-0.888$ \\
\end{tabular} & 82.6 & - & & - & - & - \\
\hline (1M-5NNAP) & 0.184 & $0.014-12.24$ & 93.1 & - & & - & - & - \\
\hline (1M-6NNAP) & 0.153 & $0.017-2.50$ & 96.6 & - & & - & - & - \\
\hline (2M-4NNAP) & 0.203 & $0.020-2.84$ & 86.2 & - & & - & - & - \\
\hline (2-NBP) & 0.236 & $0.022-3.06$ & 100 & - & & - & - & - \\
\hline (3-NBP) & 0.084 & $0.011-2.14$ & 89.7 & - & & - & - & - \\
\hline (4-NBP) & 0.009 & $0.009-0.77$ & 51.7 & - & & - & - & - \\
\hline (5-NACE) & 0.126 & $0.019-1.31$ & 96.6 & - & & - & - & - \\
\hline (2-NFLU) & 0.476 & $0.006-2.74$ & 100 & - & & - & $\begin{array}{l}5.81 \times 10^{-5} \\
6.19 \times 10^{-4}\end{array}$ & $\begin{array}{l}8.2 \times 10^{-5}- \\
5.910^{-4}\end{array}$ \\
\hline (2-NPHE) & 0.101 & $0.008-0.790$ & 93.1 & - & & - & - & - \\
\hline$(3-\mathrm{NPHE})^{\mathrm{AV}}$ & 0.067 & $<$ LOD -0.500 & 37.9 & - & & - & $\begin{array}{l}2.2 \times 10^{-5}- \\
0.206\end{array}$ & $\begin{array}{l}1.21 \times 10^{-4} \\
9.87 \times 10^{-3}\end{array}$ \\
\hline (9-NPHE) & 0.041 & $0.007-0.650$ & 72.4 & - & & - & $\begin{array}{l}6.83 \times 10^{-4}- \\
0.179\end{array}$ & $\begin{array}{l}4.85 \times 10^{-4}- \\
6.69 \times 10^{-3}\end{array}$ \\
\hline (2-NANT) & $<$ LOD & - & 82.8 & - & & - & - & - \\
\hline (9-NANT) & 0.041 & $<$ LOD - 2.83 & 65.5 & - & & - & - & - \\
\hline$(2-N F L T)^{A V}$ & $<$ LOD & - & 37.9 & - & & - & - & - \\
\hline$(3-N F L T)^{A V}$ & 0.518 & $0.112-4.52$ & 44.8 & - & & - & - & - \\
\hline$(2-N P Y R)^{A V}$ & 0.011 & $<$ LOD -0.153 & 17.2 & - & & - & - & - \\
\hline$(4-\mathrm{NPYR})^{\mathrm{AV}}$ & $<$ LOD & - & 13.8 & - & & - & $\begin{array}{l}6.4 \times 10^{-5}- \\
9.8 \times 10^{-4}\end{array}$ & $\begin{array}{l}72 \times 10^{-5}- \\
6.24 \times 10^{-4}\end{array}$ \\
\hline (7-NBaA) & $<$ LOD & - & 89.6 & - & & - & - & - \\
\hline ontinued & & & & & & & & \\
\hline
\end{tabular}




\begin{tabular}{|c|c|c|c|c|c|c|c|c|}
\hline \multirow{2}{*}{\multicolumn{4}{|c|}{ This work }} & \multicolumn{3}{|c|}{ Comparison with other published works } & \multirow{2}{*}{\multicolumn{2}{|c|}{ Uno et al. ${ }^{41}$}} \\
\hline & & & & \multicolumn{2}{|c|}{ Szczybelski et al. ${ }^{16}$} & \multirow{2}{*}{\begin{tabular}{|l|} 
Nesto et $a l .^{38}$ \\
Range $\left(\mu \mathrm{g} \mathrm{g}^{-1}\right)$ \\
\end{tabular}} & & \\
\hline PAHs & Median & Range & & Range $\left(\mu \mathrm{g} \mathrm{g}^{-1}\right)$ & & & Range $\left(\mu g g^{-1}\right)$ & \\
\hline Compounds & $\left(\mu \mathrm{g} \mathrm{g}^{-1} \mathrm{dw}\right)$ & $\left(\mu \mathrm{g} \mathrm{g}^{-1} \mathrm{dw}\right)$ & FOD (\%) & N. ciliata* & A. virens* & P. rullieri* & Oysters & Mussels \\
\hline$(6-\mathrm{NBaP})$ & 1.715 & $0.296-19.2$ & 96.6 & - & & - & - & - \\
\hline$(1-\mathrm{NBeP})$ & 1.513 & $0.09-7.99$ & 93.1 & - & & - & - & - \\
\hline$(3-\mathrm{NBeP})$ & 1.140 & $0.517-11.30$ & 79.3 & - & & - & - & - \\
\hline (1-NPYR) & 0.131 & $0.017-2.32$ & 72.4 & - & & - & $\begin{array}{l}4.52 \times 10^{-5}- \\
2.07 \times 10^{-4}\end{array}$ & $\begin{array}{l}32 \times 10^{-5}- \\
31 \times 10^{-4}\end{array}$ \\
\hline (6-NCRY) & 0.133 & $0.026-2.83$ & 75.9 & - & & - & $\begin{array}{l}2.868 \times 10^{-5}- \\
7.47 \times 10^{-5}\end{array}$ & $\begin{array}{l}1.21 \times 10^{-4}- \\
2.10 \times 10^{-3}\end{array}$ \\
\hline (3-NBA) & 0.505 & $0.110-5.18$ & 100 & - & & - & - & - \\
\hline
\end{tabular}

Table 1. Range of concentration (dry weight), frequency of detection for polycyclic aromatic compounds founds in the polychaete organisms collected in Todos os Santos Bay (BTS). A comparison with other works is performed. Nephtys ciliata (Müller, 1788), Alitta virens (M. Sars, 1835), Perinereis rullieri Pilato, 1974, *Polychaetes. FOD, Frequency of detection. ${ }^{\mathrm{AV}}$ Average. dw, dry weight.

higher ability to bioaccumulate 1-NNAP than Thalassodrilides sp. In our study, 1-NNAP and 2-nitronaphthalene (2-NNAP) were found at levels below those reported in P. nuntia ${ }^{40}$. However, it should be kept in mind that the study by K. Ito et al..$^{40}$ involved experiments in controlled conditions whereas in our study different polycyclic compounds were determined in polychaetes specimens, mainly belonged to the Opheliidae, Capitellidae, Spionidae, Goniadidae, Syllidae, and Orbiniidae families, collected from the wild and directly analyzed without any exposure to chemical substances at the laboratory. Therefore, these studies are not directly comparable.

Regarding sampling of other organisms from marine environments, it is worth mentioning that 1-NNAP and 2-NNAP contents were also determined by Uno et al. ${ }^{41}$ in mussel and oyster samples collected from Osaka Bay. The concentrations in mussels ranged from $4.38 \times 10^{-4}$ to $0.0076 \mu \mathrm{gg}^{-1}$ and $3.95 \times 10^{-4}$ to $0.0052 \mathrm{\mu g} \mathrm{g}^{-1}$ for 1-NNAP and 2-NNAP, respectively. In oysters, the 2 -NNAP concentrations exceeded $0.018 \mu \mathrm{gg}^{-1}$, which were very similar to the concentrations in most polychaete samples in this study. In addition, the concentrations of 3-nitrophenanthrene (3-NPHE) $\left(0.206 \mu \mathrm{gg}^{-1} \mathrm{dw}\right)$ and 9-nitrophenanthrene (9-NPHE) $\left(0.179 \mu \mathrm{gg}^{-1} \mathrm{dw}\right)$ found in oysters ${ }^{41}$ were the highest. However, they are lower than the maximum concentrations in polychaetes determined in this study, which ranged from 0.026 to $0.500 \mu \mathrm{g} \mathrm{g}^{-1} \mathrm{dw}$, and from 0.007 to $0.650 \mu \mathrm{g} \mathrm{g}^{-1} \mathrm{dw}_{\text {for }} 3$-NPHE and 9-NPHE, respectively.

Nitrated PAHs (such as 1M-5NNAP, 1-nitrobenzo(e)pyrene (1-NBeP), 3-nitrobenzo(e)pyrene (3-NBeP), and 6-nitrobenzo(a)pyrene (6-NBaP)) were found in high concentrations in some samples collected from BTS. The median concentrations of these compounds ranged from $0.184 \mu \mathrm{gg}^{-1} \mathrm{dw}(1 \mathrm{~N}-5 \mathrm{NNAP})$ to $1.72 \mu \mathrm{gg}^{-1} \mathrm{dw}$ (6-NBAP). Other nitro-PAHs were found at detection frequencies higher to $72 \%$, except for 4-nitrobiphenyl (4-NBP), 3-NPHE, 2-nitrofluoranthene (2-NFLT), 3-nitrofluoranthene (3-NFLT), 2-nitropyrene (2-NPYR), and 4-nitropyrene (4-NPYR) which had detection frequencies of 13.8-51.7\%. In addition, some oxy-PAHs (such as 1,4-benzoquinone (1,4-BQ), 1,2-naphthoquinone (1,2-NQ), 1,4-naphthoquinone (1,4-NQ), and 9,10-anthraquinone (9,10-AQ)) were detected at high frequencies (lower than 93\%), although 1,2-NQ was below the limit of detection (LOD). The median concentrations of oxy-PAHs within the range of $0.031 \mu^{-1} \mathrm{gg}^{-1} \mathrm{dw}$ (BA) to $0.221 \mu \mathrm{gg}^{-1} \mathrm{dw}(9,10-\mathrm{AQ})$. The oxy-PAH 9,10-phenanthraquinone (9,10-PQ) showed a low frequency of detection and the lowest concentration range compared to other oxy-PAHs ( $\left.<\mathrm{LOD}-0.823 \mu \mathrm{gg}^{-1} \mathrm{dw}\right)$.

It is notable that the potent mutagenic and carcinogenic compound 3-NBA was detected in all samples with concentrations ranging from 0.110 to $5.18 \mu \mathrm{gg}^{-1} \mathrm{dw}$. Benzanthrone, another important mutagenic pollutant, was detected in $82.8 \%$ of samples with concentrations ranging from $<\mathrm{LOD}$ to $0.520 \mu \mathrm{g} \mathrm{g}^{-1} \mathrm{dw}$. As far as we know, there are no reports in the literature regarding 3-NBA and BA concentrations in marine organisms, and therefore, these concentrations were determined for the first time in polychaetes in this study. A chromatogram (SIM mode) of 3-NBA peak detected in a real sample is shown in Fig. S2.

To the best of our knowledge, there are no studies addressing diagnostic ratios, and their related reference values against different sources, for nitro- and oxy-PAHs in living organisms. Hence, it is difficult to accurately determine the main sources of these compounds that were found in polychaete samples by using diagnostic ratios. Alternatively, PCA and ternary correlations combined with diagnostic ratios calculations (for PAHs only) may enable the determination of major sources of nitro- and oxy- PAHs. PCA was employed in order to reduce the dataset dimensionality while preserving the majority of its statistical information. This technique is an efficient statistical tool that allows identification of samples containing relevant information in loadings and scores in bidimensional plots ${ }^{42}$. For reducing the number of variables, we divided our results according to the chemical classes and the number of rings in the chemical structure. In this way, we conveniently grouped our results into PAHs, oxy-PAHs, and nitro-PAHs. For each of them, we then grouped the PACs containing 2, 3, 4, 5, and 6 rings separately. For PAHs, we grouped those with 3 rings (ACE, ACY, FLU, PHE, and ANT), 4 rings (FLT, $\mathrm{PYR}, \mathrm{BaA}$, and chrysene $(\mathrm{CRY}))$, 5 rings $(\mathrm{BbF}$, benzo(k)fluoranthene $(\mathrm{BkF}), \mathrm{BaP}$, perylene (PER), and dibenzo(a,h)anthracene (DBA)), and 6 rings (indeno( $123 \mathrm{~cd}$ )perylene (IND) and BgP). Similarly, we did the same for nitro-PAHs with 2 rings (1-NNAP, 2-NNAP, 1-methyl-4nitronaphthalene (1M-4-NNAP), 1M-5-NNAP, 1-methyl-6-nitronaphthalene (1M-6-NNAP), 2-methyl-4nitronaphthalene (2M-4-NNAP), 2-nitrobiphenyl (2-NBP), 3-nitrobiphenyl (3-NBP), and 4-NBP), 3 rings (5-nitroacenaphthene (5-NACE), 2-nitrofluorene 


\begin{tabular}{|l|c|c|c|c|c|}
\hline Variables & PC1 & \multicolumn{1}{|l|}{ PC2 } & \multicolumn{1}{l|}{ PC3 } & \multicolumn{1}{l|}{ PC4 } & \multicolumn{1}{l|}{ PC5 } \\
\hline NAP & $\mathbf{0 . 8 4 7}$ & 0.478 & 0.014 & 0.033 & -0.142 \\
\hline 3-Rings & 0.264 & $\mathbf{0 . 9 2 1}$ & 0.154 & -0.002 & 0.029 \\
\hline 4-Rings & 0.267 & $\mathbf{0 . 7 4 6}$ & -0.176 & 0.026 & 0.249 \\
\hline 5-Rings & $\mathbf{0 . 9 0 8}$ & 0.270 & -0.170 & 0.109 & -0.144 \\
\hline 6-Rings & $\mathbf{0 . 7 6 5}$ & 0.332 & -0.314 & 0.083 & 0.225 \\
\hline COR & 0.036 & -0.063 & -0.166 & -0.068 & $\mathbf{0 . 9 0 0}$ \\
\hline 1,4-BQ & 0.055 & -0.019 & 0.061 & $\mathbf{0 . 9 3 9}$ & -0.053 \\
\hline 1,2-NQ & 0.068 & $\mathbf{0 . 9 5 4}$ & 0.030 & -0.030 & -0.105 \\
\hline 1,4-NQ & $\mathbf{0 . 8 4 5}$ & 0.189 & 0.227 & -0.134 & 0.282 \\
\hline 9,10 -AQ & 0.160 & 0.119 & $-\mathbf{0 . 7 1 4}$ & -0.030 & 0.360 \\
\hline 9,10-PQ & -0.168 & -0.190 & -0.609 & -0.294 & 0.090 \\
\hline N-2 Rings & $\mathbf{0 . 9 2 8}$ & 0.191 & 0.168 & 0.050 & 0.145 \\
\hline N-3 Rings & 0.461 & $\mathbf{0 . 8 6 6}$ & -0.043 & 0.016 & 0.017 \\
\hline N-4 Rings & 0.306 & $\mathbf{0 . 9 0 6}$ & -0.088 & 0.005 & -0.055 \\
\hline N-5 Rings & $\mathbf{0 . 7 8 6}$ & 0.157 & 0.021 & 0.129 & 0.267 \\
\hline 3-NBA & $\mathbf{0 . 6 5 9}$ & 0.070 & 0.374 & -0.276 & 0.274 \\
\hline BA & $\mathbf{0 . 8 8 2}$ & 0.268 & -0.190 & -0.010 & -0.239 \\
\hline Total variance (\%) & 48.9 & 14.1 & 10.2 & 6.49 & 5.47 \\
\hline Cumulative (\%) & 48.9 & 62.9 & 73.1 & 79.6 & 85.1 \\
\hline
\end{tabular}

Table 2. Rotated factor loadings of extracted principal components.

(2-NFLU), 2-NPHE, 3-NPHE, 9-NPHE, 2-nitroanthracene (2-NANT), and 9-nitroanthracene (9-NANT)), 4 rings (2-NFLT, 3-NFLT, 2-NPYR, 4-NPYR, 7-nitrobenzo(a)anthracene (7-NBaA), 1-nitropyrene (1-NPYR), and 6-nitrochrysene (6-NCRY)), and 5 rings (6-nitrobenzo(a)pyrene (6-NBaP), 1-nitrobenzo(e)pyrene (1-NBeP), and 3-nitrobenzo(e)pyrene (3-NBeP)). This strategy was also employed by M. Ito et al. ${ }^{4}$, allowing a reduction of the number of variables without losing the ability of interpreting data. Thus, it was obtained a $29 \times 17$ data matrix (29 samples against 17 chemical species). Autoscaling was employed as an initial pretreatment to assure that all variables presented the same importance. A preliminary evaluation of the correlation matrix showed significant correlations for most of the variables. The criteria for the extraction of principal component (PCs) was based on eigenvalues $\geq 1$ and the percentage of variance in each PC (Table 2). Please, also see Figs. S7 and S8.

As shown in Table 2, five PCs were extracted by explaining $85.1 \%$ of the cumulative variance in the dataset. The PC1 explained more than $48 \%$ of the variance and was characterized by high loadings of NAP and PAHs containing 5 and 6 rings, nitro-PAHs containing 2 and 5 rings, 1,4-NQ, 3-NBA, and BA. In turn, PC2, which explained $14.1 \%$ of the variance, was characterized by high loadings for 3- and 4-ring PAHs, 1,2-NQ, and 3- and 4-ring nitro-PAHs. The 3- and 4-ring PAHs were strongly correlated with their nitrated analogues (3 and 4-ring nitro-PAHs). The PC3 and PC4 were characterized by high loadings for quinones, and PC5 showed high loadings for COR. The distribution of variables and samples in bidimensional graphs (score and loadings) can be seen in Figs. S4 and S5, where also it is presented a brief discussion about sample discrimination.

These PCA results may suggest that chemical species grouped in a specific PC (species presenting high loadings in the same given PC) might be either formed, have undergone similar physical-chemical processes, and/ or been absorbed in polychaetes in a similar way. For instance, in PC1, NAP presented a high loading along with 1,4-NQ and N-2 rings. This may be representative of different rates of polychaetes absorption of these species or even the oxy- and nitro-derivatives of NAP (1,4-NQ and NNAP, respectively). Similar behavior was also observed in PC2 for 3-and 4-ring PAHs and nitro-PAHs. However, this hypothesized process is not well known or well understood and therefore it should be better studied become accepted. Indeed, this kind of reasoning should be taken very cautiously, and this hypothesis should be comprehensively studied prior to it being considered probable. However, in PC1, there were high loadings of 3-NBA and BA. It has been reported that 3-NBA is directly emitted by incomplete combustion of fossil diese $\mathrm{l}^{21,36,43-45}$. Although we have not located studies reporting BA levels in the atmosphere, it may be reasonable to accept that BA and 3-NBA may be formed in the same process. However, this hypothesis should be further addressed in future studies. These hypotheses are somewhat feasible under specific environmental conditions, for example, BA and 3-NBA may be transferred from the atmosphere to water bodies. Even though PC3, PC4, and PC5 explained small portions of the dataset, they were statistically significant for 9,10-AQ, 1,4-BQ, and COR, respectively.

Molecular diagnostic ratios. The use of PAH ratios has been widely applied to determine possible sources of contamination in the aquatic environment ${ }^{46,47}$. Although we are aware that diagnostic ratios should be used carefully since there is some inherent uncertainty associated with them, we chose to use the ratios involving PAH isomers with similar relative thermodynamic stabilities ${ }^{48,49}$ to avoid distortions in the source inferencing. The results showed that BA and 3-NBA were well correlated $(r=0.7908, p=0.0001 ;$ Fig. 1$)$, which supports the suggestion that they have close origins. In turn, compared to the other PACs, BA and 3-NBA presented strong ternary correlations ( $r>0.75$ ) (Fig. 1; Table 3) with 2-ring (NAP, 1-NNAP, 2-NNAP, 2-NBP, 3-NBP, 4-NBP, 1-methyl-6-NNAP, and 1-methyl-4-NNAP), 3-ring (ACE, 5-NACE, 2-NFLU, and 2-NPHE), 5-ring (BkF, PER, 

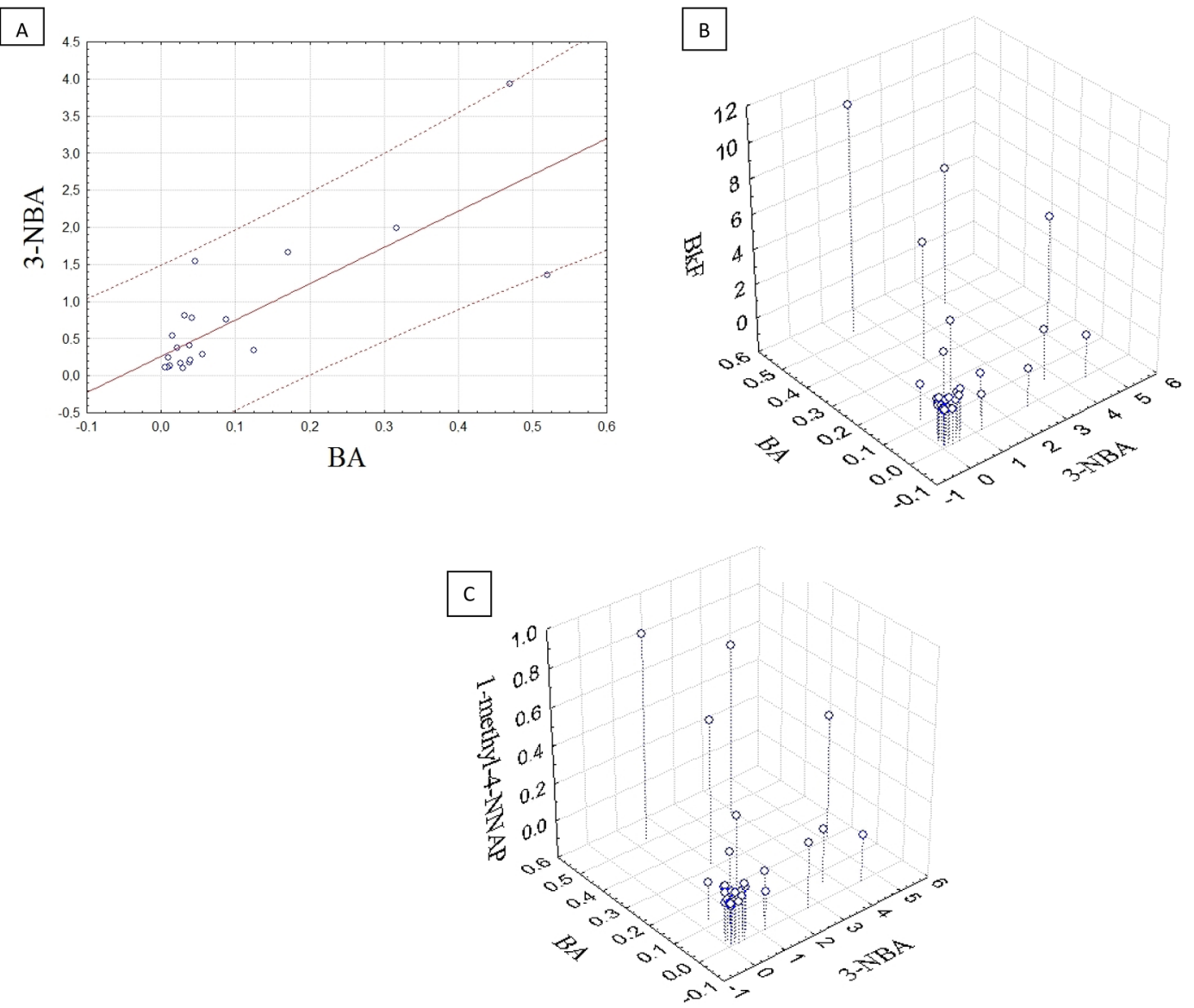

Figure 1. (A) Binary correlation plot between 3-NBA and BA $(y=0.2625+4.8938 \times ; \mathrm{R}=0.7908 ; \mathrm{p}<0.0001)$; (B) 3D scatterplot of ternary correlation between $\mathrm{BA}$ and 3-NBA against $\mathrm{BkF}(\mathrm{R}(\mathrm{z} / \mathrm{xy})=0.9474 ; \mathrm{p}<0.0001)$ and (C) 3D scatterplot of ternary correlation between BA and 3-NBA against 1-methyl-4-NNAP (R(z/xy) $=0.9667$, $\mathrm{p}<0.0001)$.

and 3-NBeP), and 6-ring PAHs and nitro-PAHs. Indeed, this is in good agreement with the chemical species found to have high loadings in PC1 (Table 2).

Accordingly, we considered the following ratios: IND/(IND + BgP), ANT/(ANT + PHE), FLT/PYR, PHE/ $\mathrm{ANT}$, and $\sum \mathrm{LMW} / \sum \mathrm{HMW}$ disposed as cross plots (Fig. 2) within their respective reference values to discriminate pyrogenic from petrogenic contributions $\mathrm{s}^{46,47}$.

Firstly, ANT/(ANT + PHE) $>0.10$ indicated pyrogenic sources while ANT/(ANT + PHE) $<0.10$ indicated petrogenic inputs. Similarly, IND/(IND $+\mathrm{BgP})<0.2$ indicated petrogenic inputs, and $>0.2$ indicated pyrogenic inputs. Our data showed mixed contributions, with a predominance of petrogenic inputs. In general, petrogenic sources possess a higher predominance of PHE over ANT, and of PYR over FLT ${ }^{46}$. In this way, PHE/ANT $>10$ and FLT/PYR $<1.0$ represented petrogenic contributions (Fig. 2B). In Fig. 2B, the data ranged from a small to a high predominance of PHE over ANT, and FLT/PYR values varied from approximately 0.5 to 2.0 , indicating contributions from both pyrogenic and petrogenic sources. The data distribution in Fig. 2C showed ANT/ $(\mathrm{ANT}+\mathrm{PHE})>0.1 \mathrm{e} \mathrm{IND} /(\mathrm{IND}+\mathrm{Bg})<0.2$ ratios, suggesting a significant contribution of petrogenic sources.

The LMW to HMW PAH ratios versus IND/(IND + BgP) is presented in Fig. 2C. According to Miguel-Gallo et al. ${ }^{50}$ pyrogenic (combustion) processes produce mainly HMW compounds (4-6 rings), whereas a higher proportion of LMW compounds (2-3 rings) is generally found in unburned petroleum. In this way, $\sum \mathrm{LMW} / \sum \mathrm{HMW}>1.0$ indicates petrogenic predominance over pyrogenic $\left(\sum \mathrm{LMW} / \sum \mathrm{HMW}<1.0\right)$ inputs. By calculation of the LMW/ $/ \mathrm{HMW}$ ratios, our results show that the petrogenic contribution was prevalent.

For BTS, the contributing petrogenic sources may be the traffic of small boats or commercial ships (since two important harbors are located in this bay), petroleum exploitation, and complex petrochemical discharges. Pyrogenic sources appear to be fossil fuel combustion processes occurring in the vicinity of the BTS. It is likely the polycyclic levels found in polychaetes in the present study may be a result of petroleum exploitation in the area together to the transit of boats and other vessels around the bay. Additionally, PACs primarily emitted from automobiles to atmosphere and then transferred to water bodies might also be a contributing route explaining at least partially to the found PAC levels in BTS within the present study. 

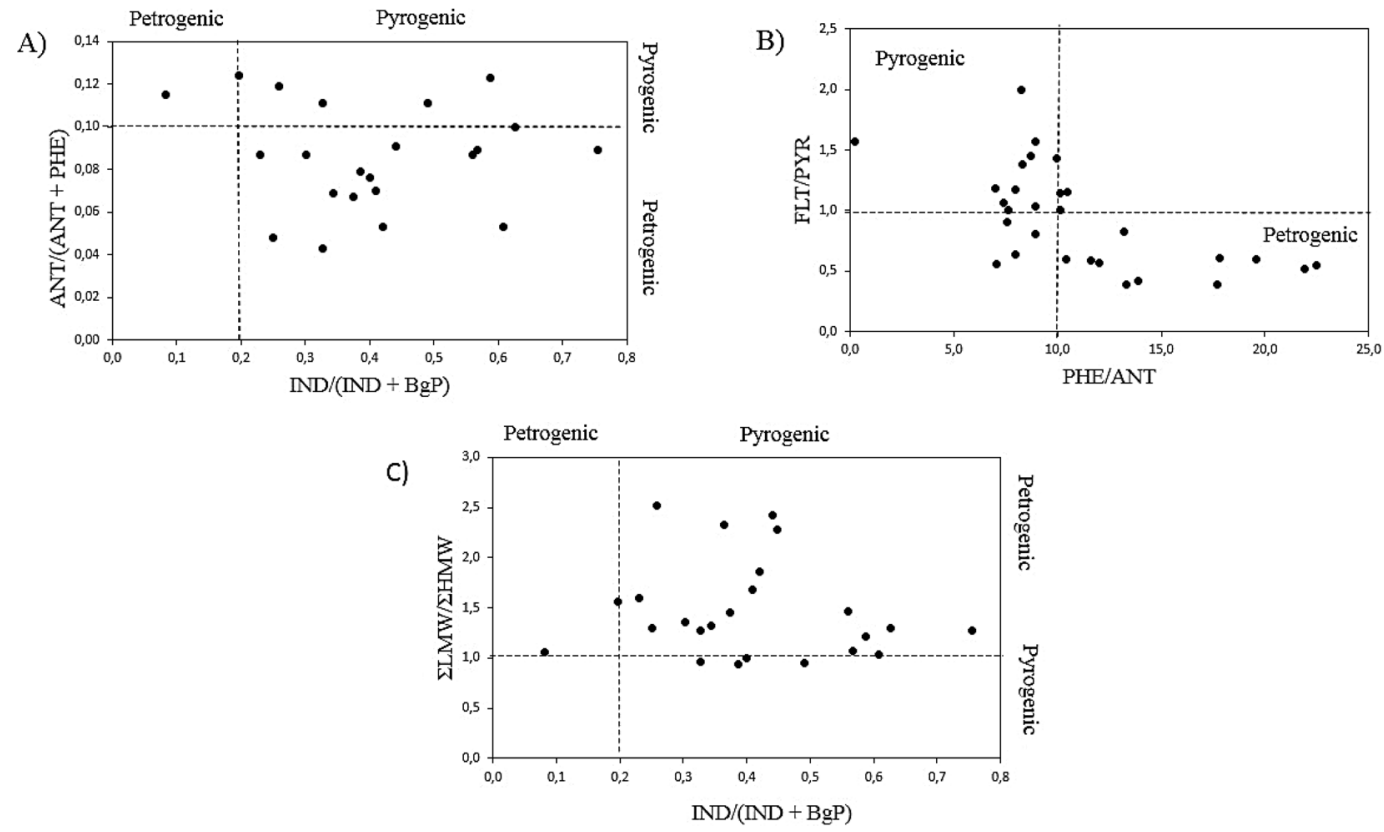

Figure 2. Selected molecular diagnostic PAH ratios in marine polychaetes: (A) ANT(ANT + PHE) versus IND(IND + BgP); (B) FLT/PYR versus PHE/ANT; and (C) $\Sigma$ LMW/ $\Sigma$ HMW versus IND(IND + BgP).

Concluding remarks. For the first time it is reported the occurrence of potent mutagenic 3-NBA - together to other nitro- and oxy-PAHs - in polychaete organisms. The use of statistical analysis allowed the identification of possible sources of nitrated and oxygenated derivatives of HPAs. Contributing sources were petrogenic (from the traffic of small boats or commercial ships, petroleum exploitation and petrochemical complex discharges) as well as pyrogenic sources seem to be fossil fuel combustion processes occurring the vicinities of the bay.

\section{Methods}

Reagents and standards. Nitro-PAHs certified standards SRM $2264^{51}$ composed by 1-nitronaphthalene (1-NNAP), 2-nitronaphthalene (2-NNAP), 1-methyl-4-nitronaphthalene (1-methyl-4-NNAP), 1-methyl-5-nitronaphthalene (1-methyl-5-NNAP), 1-methyl-6-nitronaphthalene (1-methyl-6-NNAP), 2-methyl-4-nitronaphthalene (2-methyl-4-NNAP), 2-nitrobiphenyl (2-NBP), 3-nitrobiphenyl (3-NBP), 4-nitrobiphenyl (4-NBP), 5-nitroacenaphthene (5-NACE), and 2-nitrofluorene (2-NFLU) and SRM $2265^{52}$ (2-nitrophenanthrene (2-NPHE), 3-nitrophenanthrene (3-NPHE), 9-nitrophenanthrene (9-NPHE), 2-nitroanthracene (2-NANT), 9-nitroanthracene (9-NANT), 2-nitrofluoranthene (2-NFLT), 3-nitrofluoranthene (3-NFLT), 1-nitropyrene (1-NPYR), 2-nitropyrene (2-NPYR), 4-nitropyrene (4-NPYR), 6-nitrochrysene (6-NCRY), 7-nitrobenz[a] anthracene (7-NBaA), 3-nitrobenzanthrone (3-NBA), 6-nitrobenzo[a]pyrene (6-NBaP), 1-nitrobenzo[e]pyrene (1-NBeP), and 3 nitrobenzo[e]pyrene (3-NBeP) were purchased from NIST (USA). EPA 610 PAH mix (Supelco, USA) was also used in this study ${ }^{35}$. It was composed by acenaphthene (ACE), acenaphthylene (ACY), anthracene (ANT), benz[a]anthracene (BaA), benzo[a]pyrene (BaP), benzo[b]fluoranthene (BbF), benzo[ghi]perylene (BgP), benzo[k]fluoranthene (BkF), chrysene (CRY), dibenz[a,h] anthracene (DBA), fluoranthene (FLT), fluorene (FLU), indeno[1,2,3-d]pyrene (IND), naphthalene (NAP), phenanthrene (PHE), and pyrene (PYR), at $2000 \mu \mathrm{g}$ $\mathrm{mL}^{-1}$ each, in methanol: methylene chloride (1:1). Individual standards of coronene (COR) at $50 \mu \mathrm{g} \mathrm{mL}^{-1}$ and perylene (PER) at $1000 \mu \mathrm{g} \mathrm{mL}^{-1}$ were also used. Quinones standards, composed by 1,4-benzoquinone (1,4-BQ) (98\%), 9,10-phenanthraquinone (9,10-PQ) (95\%) and 9,10-anthraquinone (9,10-AQ) (99.4\%) were purchased from Sigma-Aldrich (St. Louis, USA). Additionally, 1,2-naphthoquinone (1,2-NQ) (90\%) and 1,4-naphthoquinone (1,4-NQ) (96.5\%) were purchased from Fluka (St. Louis, USA). A $500 \mu \mathrm{gL}^{-1}$ quinone mix stock solution was prepared by dissolving the standards in tetrahydrofuran ${ }^{35}$ (THF) (J. T. Baker, USA). Benzanthrone (BA CAS\# 82-05-3) (>98\%) was acquired from TCI (Toshima, Tokyo). In this study, stock and analytical solutions were prepared by successive dilutions in acetonitrile (ACN) (chromatographic and spectroscopic grade, J.T. Baker, USA).

Sampling site description. Samples were collected in the area of Todos os Santos Bay (BTS), located in Northwestern Brazil $\left(13^{\circ} \mathrm{S} \text { and } 38^{\circ} \mathrm{W}\right)^{53}$. This is the second-largest bay in Brazil with an area of approximately $1233 \mathrm{~km}^{2}$. Despite being located in an industrialized area, more than $60 \%$ of the perimeter of this bay is surrounded by sandy beaches, rocky shores, reefs, and mangroves. There is a petrochemical industry complex, and more than 3 million inhabitants are distributed between 15 cities $^{53}$. Petroleum exploitation has been legally conducted since 1938 in this area (which was the first location in Brazil to have petroleum extracted) and the marine environment is likely to have suffered from this activity to some degree since that time ${ }^{54}$. Even though petroleum exploitation in BTS has substantially declined since then, the Brazilian Petroleum Agency reported that $2,809,948 \mathrm{~m}^{3}$ conventional petroleum was produced in $2017^{55}$. Despite the fact that petroleum extraction in BTS 


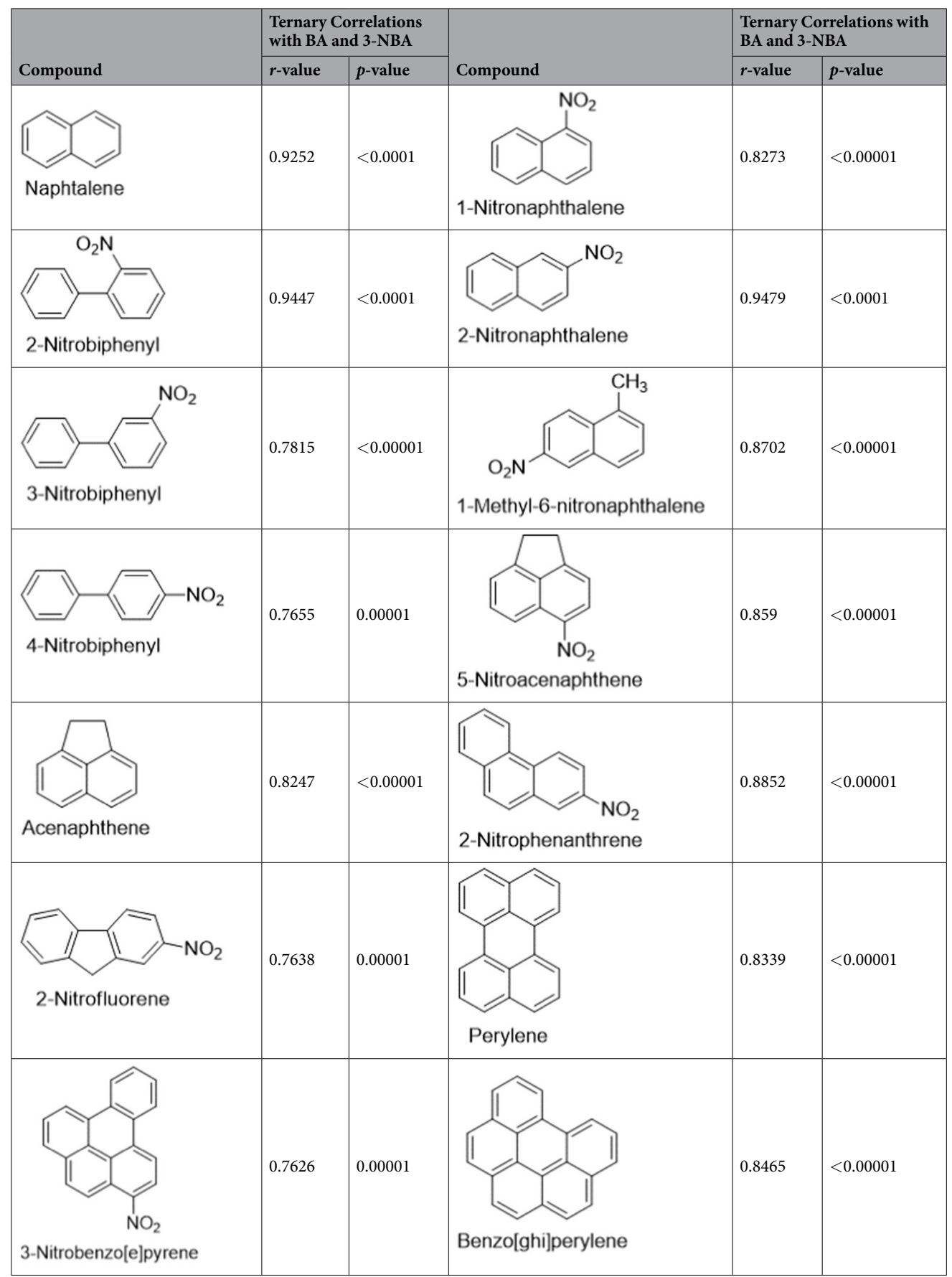

Table 3. Binary and ternary correlations among BA, 3-NBA and selected PACs.

has historically been conducted for more than 80 years, studies reporting the possible deleterious effects of this practice on the marine environment or on living organisms are scarce ${ }^{53}$.

Sampling of polychaetes. Four sites within the BTS, Northeastern Brazil, were selected for collection of organisms: Madre de Deus ( $\left.12^{\circ} 44^{\prime} 27^{\prime \prime} \mathrm{S}, 38^{\circ} 37^{\prime} 15^{\prime \prime} \mathrm{W}\right)$, Inema (12 $\left.48^{\prime} 38.3^{\prime \prime} \mathrm{S}, 38^{\circ} 29^{\prime} 39.7^{\prime \prime} \mathrm{W}\right)$, Aratu $\left(12^{\circ} 47^{\prime} 36.9^{\prime \prime} \mathrm{S}, 38^{\circ} 29^{\prime} 14.5^{\prime \prime} \mathrm{W}\right)$ and Ribeira $\left(12^{\circ} 54^{\prime} 34.2^{\prime \prime} \mathrm{S}, 38^{\circ} 29^{\prime} 51.8^{\prime \prime} \mathrm{W}\right)$. At each site, three $15-\mathrm{m}$ transects were established that were perpendicular to the shoreline, from the high tide mark, and were arranged along the intertidal zone. In each transect, three random faunal samples were collected using a stainless-steel sieve $(15 \times 15 \mathrm{~cm})$, allowing the application of same sampling effort by beach width. The polychaete worms were transferred individually to an aluminum-foil recipient containing seawater. The recipient containing the samples was closed using aluminum foil and then transported to the laboratory using a cooled box. The samples were stored in the freezer at $-21^{\circ} \mathrm{C}$. The investigated polychaete specimens showed that Opheliidae, Capitellidae, Spionidae, Goniadidae, 
Syllidae, and Orbiniidae were the most numerous families in the assessed areas. The PACs were determined in 29 polychaetes samples collected from the four sites around BTS.

Instrumentation and chromatographic analysis. In this work, we used the chromatographic conditions previously developed by Santos et al. ${ }^{35}$. In brief, a gas chromatograph coupled to a mass spectrometer GC-MS QP2010Ultra (Shimadzu, Japan), equipped with an AOC-20i autosampler and split/splitless injector operating in splitless mode at $310^{\circ} \mathrm{C}$ and purge time of $0.80 \mathrm{~min}$ was employed for PACs analysis. The injection volume was $1.00 \mu \mathrm{L}$. The chromatographic separation was performed using a Rtx-5MS gas capillary column (5\% diphenyl, $95 \%$ dimethylpolysiloxane, $30 \mathrm{~m} \times 0.250 \mathrm{~mm}$ ID $\times 0.25 \mu \mathrm{m}$ of film thickness) (Restek, Bellefonte, USA). High purity helium (99.9999\%) (White Martins, Brazil) was used as carrier gas under flow rate of $1.00 \mathrm{~mL} \mathrm{~min}^{-1}$. Oven temperature programing initiated at $70^{\circ} \mathrm{C}(2 \mathrm{~min})$, then rising from $70-200^{\circ} \mathrm{C}\left(30^{\circ} \mathrm{C} \mathrm{min}{ }^{-1}, 5 \mathrm{~min}\right)$, and $200-330^{\circ} \mathrm{C}\left(5^{\circ} \mathrm{C} \mathrm{min}^{-1}, 0.67 \mathrm{~min}\right)$. Injector temperature was set at $310^{\circ} \mathrm{C}$ and transfer line was $280^{\circ} \mathrm{C}$. Analysis was carried out at electron impact mode (EI) $(70 \mathrm{eV})$. In order to approach unequivocal peak identification and increase the sensitivity, the SIM (Selected Ion Monitoring) mode was employed and three specific ions were chosen for each compound. However, for quantification we only used the most intense ion (base ion). The same chromatographic conditions have been used successfully in the study of PAC associated to atmospheric aerosols ${ }^{35}$.

Sample treatment and miniaturized solid-liquid ultrasound-assisted extraction. Polychaete organisms were thawed in room temperature and then, they were transferred to a desiccator, being kept by $24 \mathrm{~h}$. For extraction of PACs from polychaetes, we employed a miniaturized solid-liquid extraction procedure the extraction procedure, previously developed by Santos et al. ${ }^{35}$ for extraction of PACs in PM2.5 samples. The procedure consisted of the use of a microextraction device Whatman MiniUniprep, composed by a polyethylene chamber and a plunger containing a PVDF filtering membrane. The whole device assumes the chromatography vial dimensions and it can be placed in the GC-MS autosampler for direct injection. This procedure was useful once allowed that small masses $(8-100 \mathrm{mg}$ ) obtained from polychaetes could be accurately weighted and extracted. Briefly, the polychaete samples were directly weighted into polyethylene chamber of microextraction device and $500 \mu \mathrm{L}$ of the extraction solvent ( $18 \%$ acetonitrile in dichloromethane) was added. The chamber was capped with the plunger and the extraction was carried out under sonication for 23 minutes. After that, the samples were filtered in the same microextraction device and then, they were directly injected in a GC-MS system. Figure 3 shows details of whole extraction procedure. The concentration was expressed in dry weight.

QA/QC and method validation. All glassware and material used in the analysis were cleaned according EPA Method 610 for PAHs analysis (EPA, 1984). Instrumental, solvent and/or reagent and method blanks were checked for interfering compounds. The instrumental blank was assessed by analysis of carrier gas of GC-MS in Selected Ion Monitoring (SIM) mode. Solvent and/or reagent blank was checked by extraction of solvent mixture (18\% ACN/DCM) using the microextraction device in absence of any sample. For method blank evaluation, a blank sample was prepared by extracting $100 \mathrm{mg}$ of dried and powdered polychaete three times using $20 \mathrm{~mL}$ of $18 \%$ ACN/DCM mixture. The organic fraction was discarded, and the resultant mass was dried in a desiccator by $24 \mathrm{~h}$. After that, approximately $5 \mathrm{mg}$ pre-extracted sample was weighted and extracted following the abovementioned microextraction procedure. For instrumental and solvent and/or reagent blanks were not detected interfering compounds eluting in the same retention time of target compounds. Interfering peaks corresponding to naphthalene $(0.87 \mathrm{pg}<\mathrm{LOD})$, acenaphthene $(0.31 \mathrm{pg}<\mathrm{LOD})$, fluorene $(1.09 \mathrm{pg}<\mathrm{LOD})$, phenanthrene $(4.01 \mathrm{pg}$ $<$ LOQ $)$ and anthracene $(0.09 \mathrm{pg}<\mathrm{LOD})$ were detected in the method blank. However, these concentrations were discounted from samples.

Limits of detection (LOD) and limit of quantification (LOQ) were obtained from calibration curves parameters. We considered $L O D=3 \mathrm{~s} / \mathrm{a}$ and $\mathrm{LOQ}=10 \mathrm{~s} / \mathrm{a}$, where " $\mathrm{s}$ " is the standard deviation of the linear coefficient $(\mathrm{b})$, and " $a$ " is the angular coefficient (inclination) from calibration curve ${ }^{56}$. LOD and LOQ concentrations values were converted to the minimum absolute mass either detected (LOD) or quantified (LOQ) by the GC-MS in $1.00 \mu \mathrm{L}$ of injected standard solution. For PAHs, nitro-PAHs and oxy-PAHs, the LOD in terms of absolute mass ranged from $0.83 \mathrm{pg}$ (FLT) to $3.13 \mathrm{pg}$ (PER), $0.81 \mathrm{pg}$ (2-NFLU) to $15.2 \mathrm{pg}$ (3-NPHE), and 0.58 (9,10-AQ) to 50 (1,2-NQ), respectively. Limit of quantification (LOQ) ranged from $2.75 \mathrm{pg}$ to $10.4 \mathrm{pg}, 2.70 \mathrm{pg}$ to $50.7 \mathrm{pg}$, and $1.95 \mathrm{pg}$ to $432 \mathrm{pg}$ for these same compounds. In order to assess the extraction efficiency were performed recoveries test adding known concentrations of the mix standard solution of PACs to blank polychaete sample (Table S1). The recovery values for PAHs, nitro-PAHS and oxy-PAHs ranged from $87.6 \%$ (COR) to $114 \%$ (BaP) (RSD $<11.4 \%$ ), $70.6 \%$ $(6-\mathrm{NBaP})$ to $119 \%(5-\mathrm{NACE})(\mathrm{RSD}<11.6 \%), 94.3 \%(1,4-\mathrm{BQ})$ to $145(1,4-\mathrm{NQ})(\mathrm{RSD}<11.4 \%)$ (Table S1). The RSD for the instrumental precision of this chromatographic method ranged from $0.47 \%$ (fluorene) to $5.11 \%$ $(1,4 \text {-benzoquinone })^{35}$. Surrogate deuterated standards fluorene-d10 and pyrene-d 10 were added in all sample and blanks before extraction. The recoveries of fluorene-d 10 in all samples ranged from $103 \%$ to $132 \%$ with average and RSD of $117 \pm 12 \%$ and pyrene-d 10 showed recoveries ranging from 130 to $147 \%$ with average values of $138 \pm 6.4 \%$.

For identification and confirmation of 3-NBA, we re-analyzed suspect samples and then the same samples were spiked with a NIST 2265 standard of nitro-PAHs. After overlapping the chromatogram and mass spectra obtained from SIM mode, the presence of 3-NBA was confirmed in all suspected samples. As shown in the Fig. S6, all analyzed peaks were overlapped in the same retention time. The small differences between retention times of some samples can be attributed to the change of column during analyses. The mass spectra in SIM mode obtained from fragmentation of the 3-NBA show the presence of characteristic ions $\mathrm{m} / \mathrm{z} 275$ and 245. 


\section{Dried polychaete sample was weighted and transferred to the microextraction device}
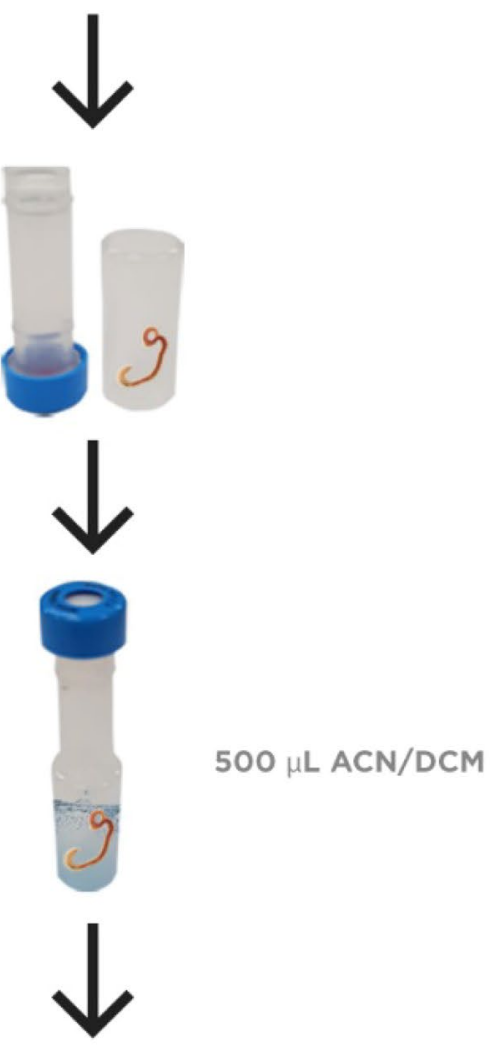

\section{Ultrasound assisted extraction $23 \mathrm{~min}$}

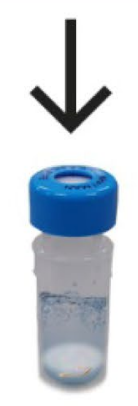

Fast filtration of the extract

\section{Direct Injection into GC-MS}

Figure 3. Schematic representation of the extraction procedure.

Statistical analysis. Principal component analysis (PCA) and ternary correlations were employed in order to simplify the dataset and to assess significant correlations between different variables (PACs). The statistical analysis was carried out using the software Statistica 7.0 (Tulsa, Oklahoma, USA). The Microsoft Excel datasheet (Microsoft, USA) was used for descriptive statistics and basic mathematical operations.

Received: 26 November 2019; Accepted: 11 February 2020;

Published online: 26 February 2020 


\section{References}

1. Chen, X. et al. CYP4 mRNA expression in marine polychaete Perinereis aibuhitensis in response to petroleum hydrocarbon and deltamethrin. Mar. Pollut. Bull. 64, 1782-1788 (2012).

2. Braga, M. A. et al. Ecotoxicology and Environmental Safety Cytotoxicity and enzymatic biomarkers as early indicators of benthic responses to the soluble-fraction of diesel oil. Ecotoxicol. Environ. Saf. 164, 21-31 (2018).

3. Ghribi, R., Correia, A. T., Elleuch, B. \& Nunes, B. Toxicity Assessment of Impacted Sediments from Southeast Coast of Tunisia Using a Biomarker Approach with the Polychaete Hediste diversicolor. Arch. Environ. Contam. Toxicol. 76, 678-691 (2019).

4. Ito, M. et al. Evaluation of bioremediation potential of three benthic annelids in organically polluted marine sediment. Chemosphere 163, 392-399 (2016).

5. Li, W. et al. mRNA expression of CYP4 in marine polychaete Marphysa sanguinea in response to benzo[a]pyrene. Acta Oceanol. Sin. 38, 46-53 (2019).

6. Perrichon, P. et al. Parental trophic exposure to three aromatic fractions of polycyclic aromatic hydrocarbons in the zebrafish: Consequences for the offspring. Sci. Total Environ. 524-525, 52-62 (2015).

7. Won, E. J. et al. Expression of three novel cytochrome P450 (CYP) and antioxidative genes from the polychaete, Perinereis nuntia

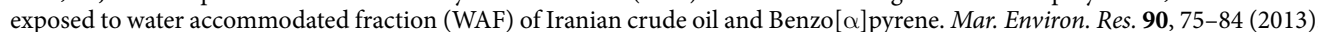

8. Zhang, Y. et al. Dietary and inhalation exposure to polycyclic aromatic hydrocarbons and urinary excretion of monohydroxy metabolites - A controlled case study in Beijing, China. Environ. Pollut. 184, 515-522 (2014).

9. Gomez Gesteira, J. L., Dauvin, J. C. \& Fraga, M. S. Taxonomic level for assessing oil spill effects on soft-bottom sublittoral benthic communities. Mar. Pollut. Bull. 46, 562-572 (2003).

10. Giessing, A. M. B., Mayer, L. M. \& Forbes, T. L. Synchronous fluorescence spectrometry of 1-hydroxypyrene: A rapid screening method for identification of PAH exposure in tissue from marine polychaetes. Mar. Environ. Res. 56, 599-615 (2003)

11. Gomes, I. D. L. et al. Effects of Barcelona harbor sediments in biological responses of the polychaete Capitella teleta. Sci. Total Environ. 485-486, 545-553 (2014).

12. Ito, M. et al. Transcription of a novel $\mathrm{P} 450$ gene varies with some factors (pollutant exposure, temperature, time, and body region) in a marine oligochaete (Thalassodrilides sp.). Mar. Pollut. Bull. 109, 344-349 (2016).

13. Lewis, C. \& Galloway, T. Genotoxic damage in polychaetes: A study of species and cell-type sensitivities. Mutat. Res. - Genet. Toxicol. Environ. Mutagen. 654, 69-75 (2008).

14. Madsen, S. D., Forbes, T. L. \& Forbes, V. E. Particle mixing by the polychaete Capitella species 1: Coupling fate and effect of a particle-bound organic contaminant (fluoranthene) in a marine sediment. Mar. Ecol. Prog. Ser. 147, 129-142 (1997).

15. Malmquist, L. M. V., Christensen, J. H. \& Selck, H. Effects of Nereis diversicolor on the transformation of 1-methylpyrene and pyrene: Transformation efficiency and identification of phase i and II products. Environ. Sci. Technol. 47, 5383-5392 (2013).

16. Szczybelski, A. S. et al. Bioaccumulation of polycyclic aromatic hydrocarbons, polychlorinated biphenyls and hexachlorobenzene by three Arctic benthic species from Kongsfjorden (Svalbard, Norway). Mar. Pollut. Bull. 112, 65-74 (2016).

17. Szczybelski, A. S., van den Heuvel-Greve, M. J., Koelmans, A. A. \& van den Brink, N. W. Biomarker responses and biotransformation capacity in Arctic and temperate benthic species exposed to polycyclic aromatic hydrocarbons. Sci. Total Environ. 662, 631-638 (2019).

18. Tairova, Z. M., Giessing, A. M. B., Hansen, R. \& Andersen, O. 1-Hydroxypyrene as a biomarker of PAH exposure in the marine polychaete Nereis diversicolor. Mar. Environ. Res. 67, 38-46 (2009).

19. Carrasco Navarro, V., Leppänen, M. T., Kukkonen, J. V. K. \& Godoy Olmos, S. Trophic transfer of pyrene metabolites between aquatic invertebrates. Environ. Pollut. 173, 61-67 (2013).

20. Driscollll, S. B. K. \& McElroy, A. E. Elimination of sediment-associated benzo [a] pyrene and its metabolites by polychaete worms exposed to. Aquat. Toxicol. 39, 77-91 (1997).

21. Enya, T., Suzuki, H., Watanabe, T., Hirayama, T. \& Hisamatsu, Y. 3-Nitrobenzanthrone, a powerful bacterial mutagen and suspected human carcinogen found in diesel exhaust and airborne particulates. Environ. Sci. Technol. 31, 2772-2776 (1997).

22. Hansen, T., Seidel, A. \& Borlak, J. The environmental carcinogen 3-nitrobenzanthrone and its main metabolite 3-aminobenzanthrone enhance formation of reactive oxygen intermediates in human A549 lung epithelial cells. Toxicol. Appl. Pharmacol. 221, 222-234 (2007).

23. Hasei, T., Nakanishi, H., Toda, Y. \& Watanabe, T. Development of a two-dimensional high-performance liquid chromatography system coupled with on-line reduction as a new efficient analytical method of 3-nitrobenzanthrone, a potential human carcinogen. J. Chromatogr. A 1253, 52-57 (2012).

24. Linhart, I. et al. Carcinogenic 3-nitrobenzanthrone but not 2-nitrobenzanthrone is metabolised to an unusual mercapturic acid in rats. Toxicol. Lett. 208, 246-253 (2012).

25. Reshetnikova, G. et al. Genotoxic and cytotoxic effects of the environmental pollutant 3-nitrobenzanthrone on bladder cancer cells. Exp. Cell Res. 349, 101-108 (2016).

26. Rossner, P. et al. Toxic effects of the major components of diesel exhaust in human alveolar basal epithelial cells (A549). Int. J. Mol. Sci. 17 (2016).

27. Birch, G. F. A review of chemical-based sediment quality assessment methodologies for the marine environment. Mar. Pollut. Bull. 133, 218-232 (2018).

28. Kwok, K. W. H. et al. Sediment quality guidelines: Challenges and opportunities for improving sediment management. Environ. Sci. Pollut. Res. 21, 17-27 (2014).

29. Perra, G., Renzi, M., Guerranti, C. \& Focardi, S. E. Polycyclic aromatic hydrocarbons pollution in sediments: Distribution and sources in a lagoon system (Orbetello, Central Italy). Transitional Waters Bull. 3, 45-58 (2009).

30. Singh, L., Varshney, J. G. \& Agarwal, T. Polycyclic aromatic hydrocarbons' formation and occurrence in processed food. Food Chem. 199, 768-781 (2016).

31. Dauvin, J. C., Bakalem, A., Baffreau, A. \& Grimes, S. Benthic ecological status of Algerian harbours. Mar. Pollut. Bull. 125, 378-388 (2017).

32. Gesteira, J. L. G. \& Dauvin, J. C. Amphipods are good bioindicators of the impact of oil spills on soft-bottom macrobenthic communities. Mar. Pollut. Bull. 40, 1017-1027 (2000).

33. Zheng, S., Chen, B., Qiu, X., Lin, K. \& Yu, X. Three novel cytochrome P450 genes identified in the marine polychaete Perinereis nuntia and their transcriptional response to xenobiotics. Aquat. Toxicol. 134-135, 11-22 (2013).

34. Hutchings, P. A. Polychaetes and allies: the southern synthesis. Fauna of Australia. Polychaeta, Myzoztomida, Pogonophora, Echiura, Spuncula. In 67-72 (CSIRO Publishing, 2000).

35. Santos, A. G. et al. A simple, comprehensive, and miniaturized solvent extraction method for determination of particulate-phase polycyclic aromatic compounds in air. J. Chromatogr. A 1435, 6-17 (2016).

36. Santos, A. G., Rocha, G. O. \& Andrade, J. B. D. Occurrence of the potent mutagens 2- nitrobenzanthrone and 3-nitrobenzanthrone in fine airborne particles. Sci. Rep. 9, 1-13 (2019).

37. Szczybelski, A. S., Diepens, N. J., van den Heuvel-Greve, M. J., van den Brink, N. W. \& Koelmans, A. A. Bioaccumulation of polycyclic aromatic hydrocarbons by arctic and temperate benthic species. Environ. Toxicol. Chem. 9999, 1-13 (2019).

38. Nesto, N., Cassin, D. \& Da Ros, L. Is the polychaete, Perinereis rullieri (Pilato 1974), a reliable indicator of PCB and PAH contaminants in coastal sediments? Ecotoxicol. Environ. Saf. 73, 143-151 (2010). 
39. Díaz-Jaramillo, M., Laitano, M. V., Gonzalez, M. \& Miglioranza, K. S. B. Spatio-temporal trends and body size differences of OCPs and PCBs in Laeonereis culveri (Polychaeta: Nereididae) from Southwest Atlantic estuaries. Mar. Pollut. Bull. 136, 107-113 (2018).

40. Ito, K. et al. Differences in the ability of two marine annelid species, Thalassodrilides sp. and Perinereis nuntia, to detoxify 1-nitronaphthalene. Chemosphere 151, 339-344 (2016).

41. Uno, S. et al. Bioaccumulation of nitroarenes in bivalves at Osaka Bay, Japan. Mar. Pollut. Bull. 63, 477-481 (2011).

42. Jolliffe, I. T. \& Cadima, J. Principal component analysis: a review and recent developments Subject Areas: Author for correspondence. Philos. Trans. R. Soc. A 374, 20150202 (2016).

43. Hayakawa, K. Environmental behaviors and toxicities of polycyclic aromatic hydrocarbons and nitropolycyclic aromatic hydrocarbons. Chem. Pharm. Bull. 64, 83-94 (2016).

44. Inazu, K. et al. Atmospheric occurrence of 2-nitrobenzanthrone associated with airborne particles in central Tokyo. Polycycl. Aromat. Compd. 28, 562-577 (2008).

45. Phousongphouang, P. T. \& Arey, J. Sources of the atmospheric contaminants, 2-nitrobenzanthrone and 3-nitrobenzanthrone. 37, 3189-3199 (2003).

46. Amin, O. A., Comoglio, L. I. \& Sericano, J. L. Polynuclear aromatic and chlorinated hydrocarbons in mussels from the coastal zone of Ushuaia, Tierra del Fuego, Argentina. Environ. Toxicol. Chem. 30, 521-529 (2011).

47. Maioli, O. L. G., Rodrigues, K. C., Knoppers, B. A. \& Azevedo, D. A. Polycyclic aromatic and aliphatic hydrocarbons in Mytella charruana, a bivalve mollusk from Mundaú Lagoon, Brazil. Microchem. J. 96, 172-179 (2010).

48. Tobiszewski, M. \& Namieśnik, J. PAH diagnostic ratios for the identification of pollution emission sources. Environ. Pollut. 162, $110-119$ (2012).

49. Yunker, M. B. et al. PAHs in the Fraser River basin: a critical appraisal of PAH ratios as indicators of PAH source and composition. Org. Geochem. 33, 489-515 (2002)

50. Miguel-Gallo, Y., Gómez-Batista, M. \& Alonso-Hernández, C. M. Levels of Polycyclic Aromatic Hydrocarbons in Perna viridis, in Cienfuegos Bay, Cuba. Polycycl. Aromat. Compd. 39, 139-147 (2019).

51. NIST. Certificate of Analysis - Standard Referece Material. SRM 2264 - Nitrated Aromatic Hydrocarbons in Methylene Chloride I. National Institute of Standards and Technology 1-3, https://www-s.nist.gov/srmors/view_detail.cfm?srm=2264, https://doi. org/10.1007/s00221-013-3781-0 (2007).

52. NIST. Certificate of Analysis - Standard Referece Material. SRM 2265 - Nitrated Aromatic Hydrocarbons in Methylene Chloride II. National Institute of Standards and Technology 1-4, https://www-s.nist.gov/srmors/view_detail.cfm?srm=2265, https://doi. org/10.1007/s00221-013-3781-0 (2007).

53. Egres, A. G., Hatje, V., Miranda, D. A., Gallucci, F. \& Barros, F. Functional response of tropical estuarine benthic assemblages to perturbation by Polycyclic Aromatic Hydrocarbons. Ecol. Indic. 96, 229-240 (2019).

54. Lucchesi, C. F. Petróleo. Estud. Avançados 12, 17-40 (1998).

55. ANP. Anuário Estatístico 2018. Anuário estatístico ANP 264, http://www.anp.gov.br/images/publicacoes/anuario-estatistico/2017/ anuario 2017.pdf (2018).

56. Ribani, M., Collins, C. H. \& Bottoli, C. B. G. Validation of chromatographic methods: Evaluation of detection and quantification limits in the determination of impurities in omeprazole. J. Chromatogr. A 1156, 201-205 (2007).

\section{Acknowledgements}

The authors thank the Brazilian funding agencies, Conselho Nacional de Desenvolvimento Científico e Tecnológico (CNPq), grant \# 442187/2018-1 (Pesquisando Kirimurê: Convergindo Educação, Ciência, Tecnologia e Inovação) and Coordenação de Aperfeiçoamento de Pessoal de Nível Superior. - Brazil (CAPES) - Finance Code 001. National Institute of Science and Technology (INCT), Centro Interdisciplinar de Energia e Ambiente (CIEnAm) and Fundo de Amparo à Pesquisa do Estado da Bahia (FAPESB) and the assistance received from Núcleo of Marketing and Communication of SENAI CIMATEC in preparing the Graphical Abstract. Last but not least, we acknowledge Professor Caio Mario Castro Castilho for helpful discussions.

\section{Author contributions}

M.C.R.S. collected, analyzed and classified the polychaetes samples and co-wrote the manuscript. A.G.S. performed the experiment and analyzed the data. S.T.M. analyzed the data and co-wrote the manuscript. M.M. Nascimento, performed the experiments, analyzed the data and co-wrote the manuscript. G.O.R., co-wrote the paper. J.B.A. conceived the experiments and co-wrote the manuscript. All authors reviewed the manuscript.

\section{Competing interests}

The authors declare no competing interests.

\section{Additional information}

Supplementary information is available for this paper at https://doi.org/10.1038/s41598-020-60369-9.

Correspondence and requests for materials should be addressed to J.B.d.A.

Reprints and permissions information is available at www.nature.com/reprints.

Publisher's note Springer Nature remains neutral with regard to jurisdictional claims in published maps and institutional affiliations.

Open Access This article is licensed under a Creative Commons Attribution 4.0 International (c) License, which permits use, sharing, adaptation, distribution and reproduction in any medium or
format, as long as you give appropriate credit to the original author(s) and the source, provide a link to the Creative Commons license, and indicate if changes were made. The images or other third party material in this article are included in the article's Creative Commons license, unless indicated otherwise in a credit line to the material. If material is not included in the article's Creative Commons license and your intended use is not permitted by statutory regulation or exceeds the permitted use, you will need to obtain permission directly from the copyright holder. To view a copy of this license, visit http://creativecommons.org/licenses/by/4.0/.

(c) The Author(s) 2020 